\title{
Standard microscopic slide preparation technique as a new and useful tool for analyzing mucilage content in marshmallow root
}

\author{
Dragana Rančić ${ }^{1,}$, Slobodan Dražić ${ }^{2}$, Svetlana Aćić ${ }^{1}$, Radenko Radošević ${ }^{1}$, ANd Zora \\ Dajić STEVANOVIĆ ${ }^{1}$ \\ ${ }^{1}$ University of Belgrade, Faculty of Agriculture, Nemanjina 6, 11080 Belgrade, Serbia \\ ${ }^{2}$ Institute for Medicinal Plant Research "Dr. Josif Pančić", Tadeuša Košćuška 1, 11000 Belgrade, Serbia \\ *Corresponding author: rancicd@agrif.bg.ac.rs
}

Received: September 25, 2018

Accepted: December 18, 2018

Published on-line: December 20, 2018

Published: December 25, 2018

\begin{abstract}
Marshmallow (Althaea officinalis L.) root is used as a drug in medicine, pharmaceutical, cosmetic as well as in food products, due to the content of mucilage with a broad range of physicochemical properties. Since mucilage content in roots depends on genotype and growing conditions, the quality control is, therefore, one of the major tasks in the rational use of the drug. In this paper we compare data for mucilage content in roots obtained by standard procedure which implies measuring of swelling ratio in dried samples, with anatomical features of roots obtained by different methods for anatomical analysis, and we have shown that anatomical method could be used for determination of mucilage content in marshmallow root.
\end{abstract}

Key words: $\quad$ root anatomy; drug; medicinal plant; Althaea officinalis

http://dx.doi.org/10.5937/leksir1838039R

\section{INTRODUCTION}

Marshmallow (Althaea officinalis L.) is a perennial herbaceous plant of family Malvaceae with fleshly, strong and branchy roots used as a drug in both folk and official medicine, in pharmaceutical and cosmetic (Khan and Abourashed, 2009). Marshmallow's root contains mucilage, hydrophilic polymers of complex polysaccharides, with a broad range of physicochemical properties, making this herb excellent demulcent, emollient, expectorant, diuretic and anti-inflammatory (Schmidgall et al., 2000). The main factor that determines the quality of the marshmallow root as the drug is the amount of mucilage. According to Pakravan et al. (2007), the structure and size of secretory tissue in Marshmallow's root correspond with the content and chemical composition of its active substances. In many medicinal plants genetic and environmental factors may influence the concentration of plant secondary compounds and active component in drugs, therefore the quality control is one of the major problems in the rational use of herbal medicines. The standard method for detecting the amount of mucilage content in marshmallow root is measuring of swelling ratio in dried samples of the root. The aim of this paper was to determine the possibility of using light microscopy for localization and estimation of mucilage content within particular root tissues and to compare the usefulness of the anatomical analysis of Marshmallow's root with the standard method of measuring mucilage content. Besides that, we try a different type of fixation and stain methods in an aim to determine the most suitable one for this type of tissue.

\section{MATERIALS AND METHODS}

\subsection{Collecting plant material}

Since the highest content of mucilage of the root drug is during the late fall and winter (Franz, 1966), roots of one year old marshmallow plant are taken out at the end of the growing season (in October). Beside root samples from commercial variety 'Vojvođanski', grown in field condition in Nova Pazova by different planting techniques (by direct sowing of seeds in the spring on production plots in the field or by repoting/planting about two months old seedlings in two terms: in the spring or in the autumn), samples of wild marshmallow plants were also used, collected from location Obrež (near to pond Obedska bara).

\subsection{Swelling index of mucilage}

From the gathered roots, the budded root parts were removed, as well as weak or undeveloped roots. After that, this material was cleaned in cold water and exposed to skin removal. The 


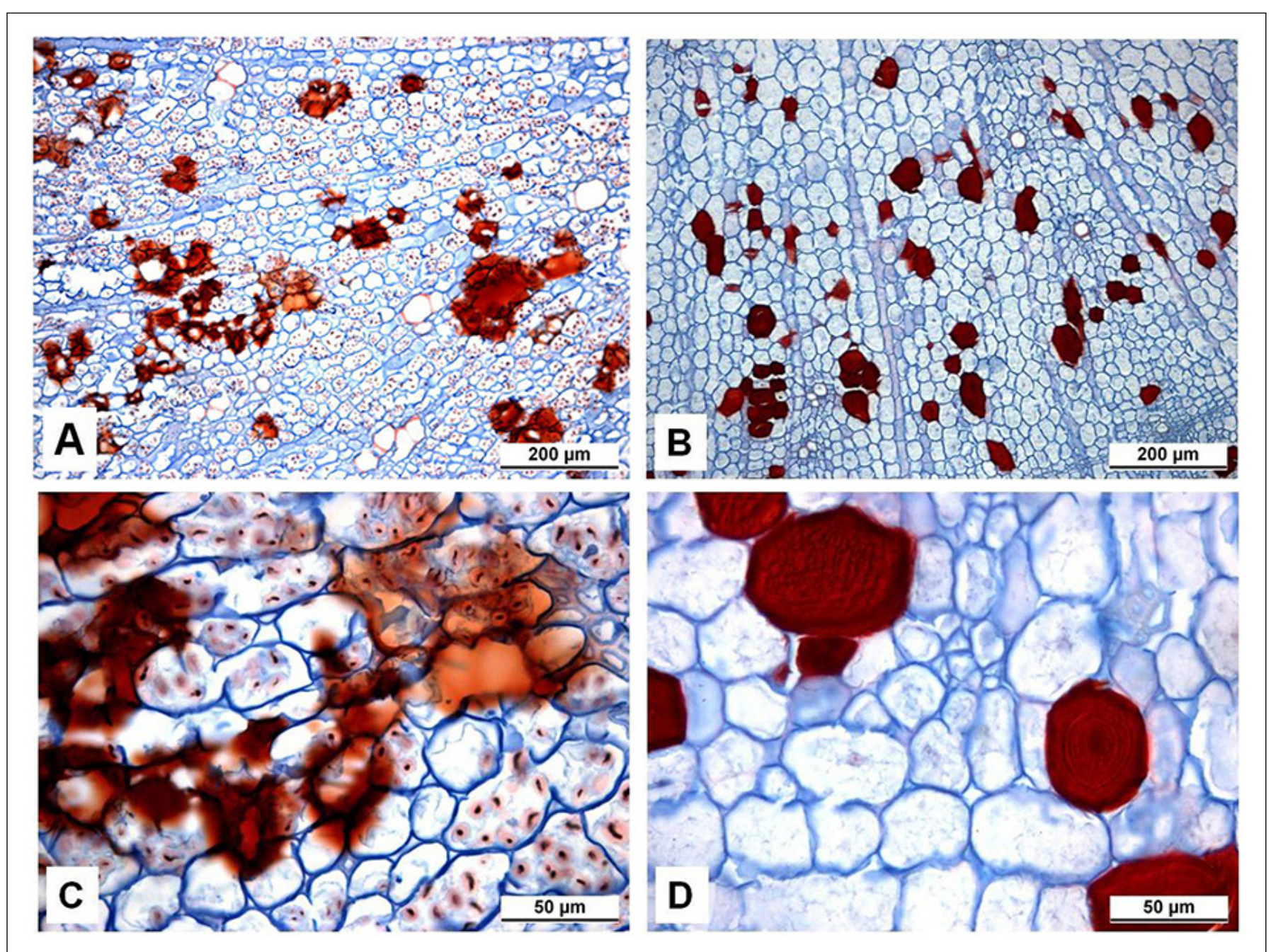

Fig. 1. Root cross section of Althaea officinalis root, stained with alcian blue and safranine: A, C-fixation in FAA; B, D- fixation in Navashin's fixative

skinless roots were cut vertically usually in four parts, thermal dried in temperatures $50{ }^{\circ} \mathrm{C}$ (until the moisture content in the drug was $7-8 \%$ ) and then cut into small pieces. The swelling index of root samples was determined according to the PE method (Ph.Eur.8.0., 2013). One gram of powder dry root material was placed in a ground glass stopper cylinder volume of $25 \mathrm{~mL}$, the height of $125 \mathrm{~mm}$ graduated in $0.5 \mathrm{~mL}$ divisions. The powder was moistened with $1 \mathrm{~mL}$ of ethanol (96\%), distilled water was added up to $25 \mathrm{ml}$, and the cylinder was closed. It was shaken vigorously every $10 \mathrm{~min}$ for $1 \mathrm{~h}$ and then allowed to stand for $3 \mathrm{~h}$. The volume of disintegrating agent including adhering mucilage was recorded.

\subsection{Anatomical study}

For anatomical analysis, fresh root samples were used and two types of microslides were prepared. For temporary microslides hand sections of non-fixed material were stained by alcian blue (Clifford et al., 2002; Edmond Ghanem et al., 2010), Molisch's test (Johansen, 1940) and ruthenium red (Ruzin, 1999), tests usually used for histochemical mucilage identification. For permanent microslides, standard paraffine method was used (Ruzin, 1999). Fresh root samples were fixed in FAA fixative or Navashin's fixative (Johansen, 1940). FAA fixative was prepared by mixing $5 \mathrm{~mL}$ of $40 \%$ formaldehyde, $5 \mathrm{~mL}$ of glacial acetic acid and $90 \mathrm{ml} 50 \%$ ethanol. Navashin's fixative was prepared by mixing equal parts of solutions $\mathrm{A}$ and $B$ immediately before placing the tissue into the fixative. Solution A was prepared by dissolving $5 \mathrm{~g}$ chromium trioxide in $50 \mathrm{~mL}$ glacial acetic acid and $320 \mathrm{ml}$ distilled water, and solution B by mixing $200 \mathrm{ml} 40 \%$ formaldehyde and 175 $\mathrm{mL}$ distilled water. After rinsing in water or $50 \%$ ethyl alcohol, dehydrating through a gradual series of ethanol $(80 \%$, $96 \%$ and absolute ethyl alcohol) was performed, followed by clearing in xylene. Samples were infiltrated with paraffin embedding medium (Histowax, 56-58 ${ }^{\circ} \mathrm{C}$ ) and cut on 6-12 $\mu \mathrm{m}$ sections by sliding microtome. Paraffin was removed from the slides passing through series of ethyl alcohol solutions, and sections were double stained with safranin-alcian blue ( $1 \%$ in $50 \% \mathrm{w} / \mathrm{v}$ ethanol) and mounted in Canada balsam. Transversal sections were observed on the LEICA DM 2000 microscope, documented by Leica DFC320 camera and analyzed in software IM 1000. The number of secretory cells per $\mathrm{mm}^{2}$ was measured.

\subsection{Statistical analysis}

Yield data were analyzed by Analysis of Variance (ANOVA) and the relation between two variables (the mucilage content and the number of secretory cells per cross-section area) was studied by the regression analysis. The coefficient of determination was estimated with software Statistica 6.0.

\section{RESULTS AND DISCUSSION}

\subsection{Swelling index of mucilage}

Swelling index of mucilage was found to be the lowest in plants grown by direct sowing from seeds $(18.0 \pm 1.6)$. Plants grown from seedlings transplanted in autumn have more mucilage $(19.7 \pm 1.7)$, while the highest values were in plants 


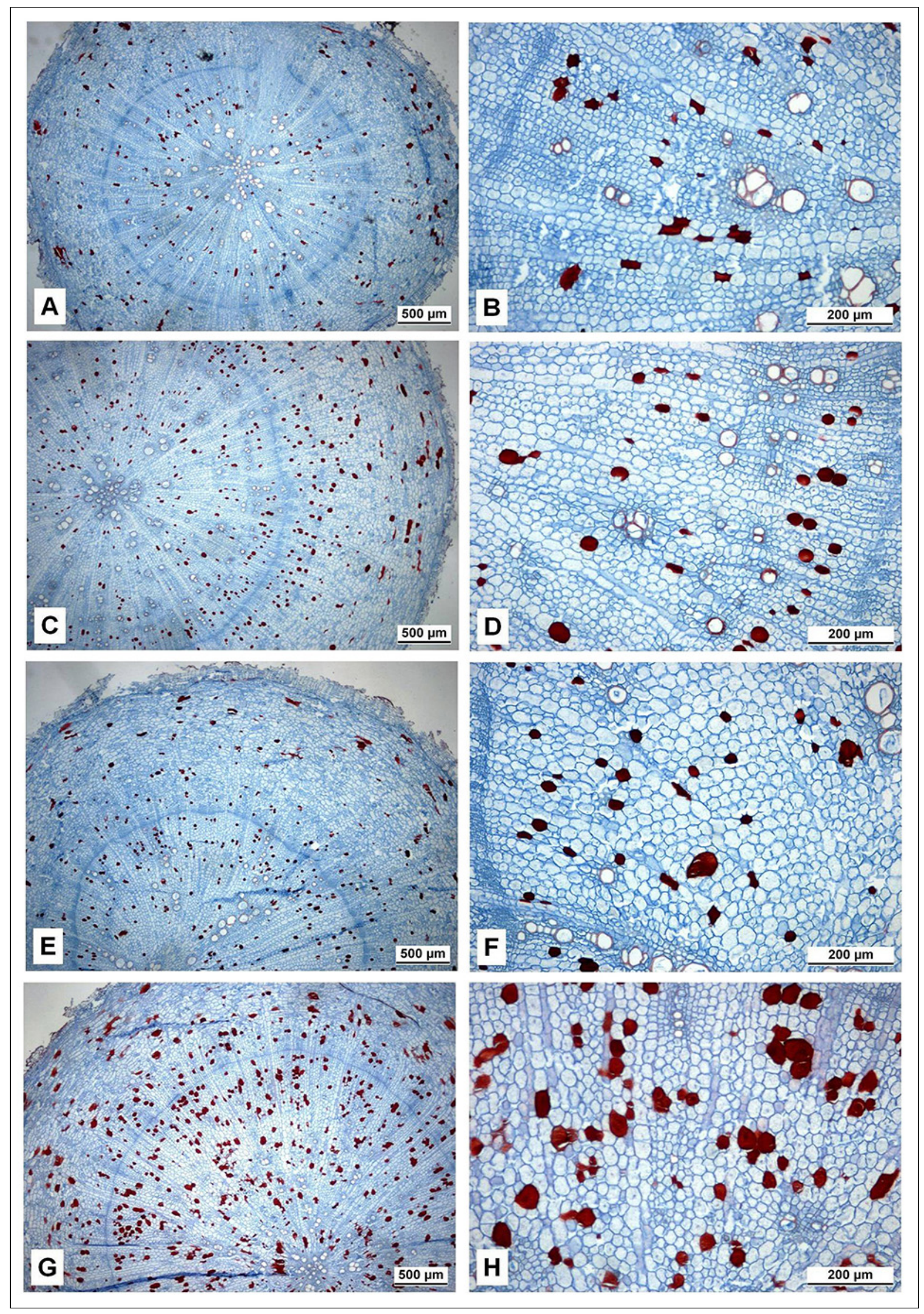

Fig. 2. Root cross section of Althaea officinalis: commercial genotype A-F: A, B- plants grown by direct sowing in the spring; C, D-plants grown over seedlings in spring; E, F- plants grown over seedlings in autumn; G, H- wild autochthonous genotype collected from location Obrež 
grown from seedlings transplanted in spring $(20.3 \pm 1.2)$ and in wild genotype $(20.3 \pm 2.0)$. Obtained values correspond with the standards for drugs Althaeae radix (JUS EB3-043) in which the swelling index is about 20.

\subsection{Anatomical study}

Marshmallow root has a large number of mucilage-containing cells mainly linked to root parenchyma of secondary phloem and xylem. Both histochemical tests, Molisch's test and treatment with Ruthenium red performed on fresh hand sections were positive for the presence of mucilage, but these sections after adding dye were not useful for mucilage content estimating, since mucilage dissolved in dye solvent and disperse all over the section (data not shown). Fixation in FAA also does not prevent rinsing mucilage form mucilage cells, so in these sections, mucilage was reflowed out from the secretory cells and spread into next parenchyma cells (Figure $1 \mathrm{~A}, \mathrm{C})$. Although there are literature data that referred mucopolysaccharides staining and its localization by Alcian blue (Edmond Ghanem et al., 2010), Molisch's test and Ruthenium red (Clifford et al., 2002), as well as in paraffin section after FAA fixation, according to our attempts, were suitable for assessing the presence of mucilage but were not suitable for quantitative assessment. Some other histochemical staining of fresh material by polychromatic dye Toluidine blue also showed mucilage dispersion through the section (Rančić et al., 2009). On the other hand, the material fixed in Navashin's fixative enabling mucilage staining, localization and measurement, since after fixation in these fixative mucilage content remains in the cells (Figure 1B,D). Although Navashin's fixative was in the past much more used in plant anatomy investigation (Chamberlain, 1933; Johansen, 1940), especially for the cytological investigation, nowadays it is almost forgotten and replaced mainly by FAA. We have shown that it is also a good choice for mucilage fixing, since after fixation mucilage content remains in the secretory cells, thus enabling localization and measurement of size and number of mucilage cells, and afterward estimating mucilage content.

According to our anatomical data, the highest percentage of the secretory tissues in the root was recorded in wild plants (Figure 2G,H) (Figure 3). These could be explained by environmental condition which are probably more stressful for plant from wild population than for commercial genotype plants grown in the field, since there are the data that content of mucilage could increased in shoot, stems and roots in some halophytic plant species in response to stress (Edmond Ghanem et al., 2010), or this could be genotypic feature of wild type genotype what need to be more investigated in the future.

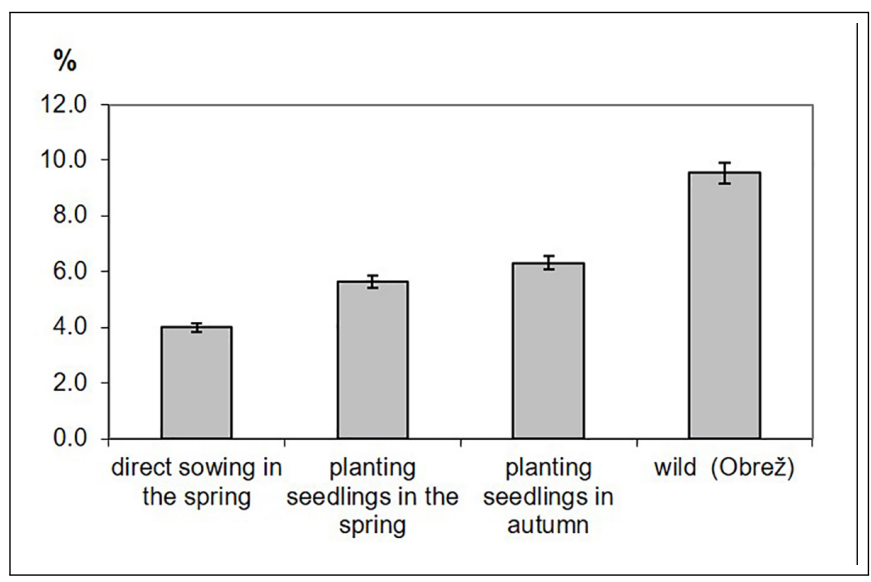

Fig. 3. The percentage of secretory tissue on root sections

\subsection{Correlation between anatomical data and swelling in- dex of mucilage}

The number of secretory cells per cross-section area in marshmallow roots corresponds with the values of swelling index of mucilage in dry drug (Figure 4), and relatively high coefficient of determination, with value higher than 0.8 , indicating possibilities of using anatomical method as a relatively fast, reliable and precise procedure for mucilage content estimation.

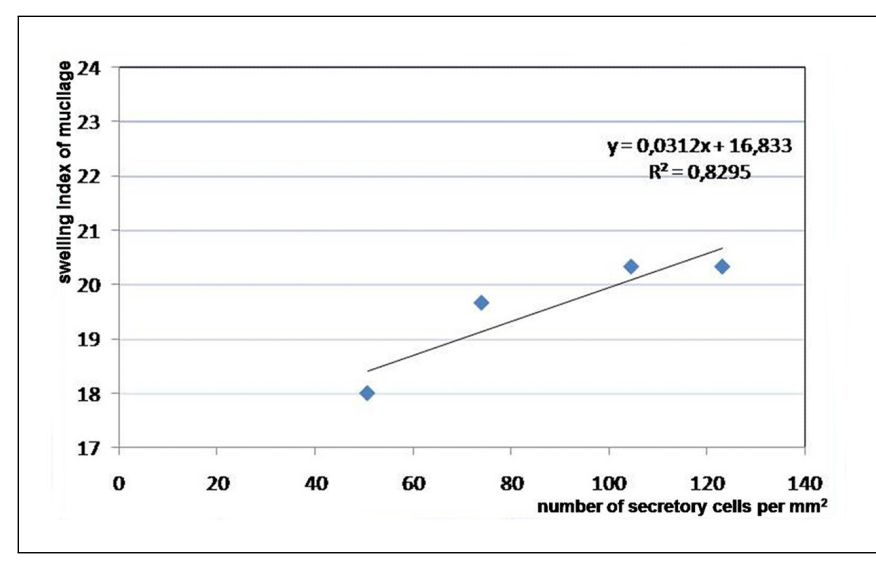

Fig. 4. Linear regression of swelling index of mucilage in dry drug and number of secretory cells per $\mathrm{mm}^{2}$ in cross section area in $\mathrm{Al}$ thaea root

\section{CONCLUSION}

However, the highest percent of the secretory tissues, what can be considered as a parameter of drug quality, was recorded not in commercial one but in wild type genotype, indicating that the future research should be focused on characterization and eventually domestication wild forms of these species.Since the number of secretory cells in marshmallow root observed from anatomical sections correspond with the amount of mucilage obtained by swelling index of mucilage, provides useful information about mucilage content and might be of a practical importance for further estimation of marshmallow drug quality. Our suggestion is that the anatomical method could be useful tool for analyzing mucilage content in marshmallow root as more rapid comparing to method of measuring swelling index of mucilage. Although Navashin's fixative is mainly used for cytological investigation, we have shown that it is also very good choice for mucilage fixing, since after fixation mucilage content remains in the secretory cells, what enabling adequate dying anatomical sections and measurement of size and number of mucilage cells, and afterwards estimating mucilage content. We strongly recommended fixing in Navashin's fixative during preparing samples for anatomical analysis for mucilage content estimating.

\section{ACKNOWLEDGMENTS}

Acknowledgment. This study was supported by the Serbian Ministry of Education and Science project (TR 20113, TR 31005 and 31057).

\section{REFERENCES}

Chamberlain, C. J. (1933). Methods in plant histology, Chicago, University of Chicago Press.

Clifford, S., Arndt, S., Popp, M. and Jones, H. (2002). Mucilages and polysaccharides in Ziziphus species (Rhamnaceae): localization, composition and physiological roles during drought-stress, Journal of Experimental Botany 53(366): 131138. 
Edmond Ghanem, M., Han, R.-M., Classen, B., Quetin-Leclerq, J., Mahy, G., Ruan, C.-J., Qin, P., Pérez-Alfocea, F. and Lutts, S. (2010). Mucilage and polysaccharides in the halophyte plant species Kosteletzkya virginica: Localization and composition in relation to salt stress, Journal of Plant Physiology 167(5): 382-392.

Franz, G. (1966). Die schleimpolysaccharide von Althaea officinalis und Malva silvestris, Planta Medica 14(01): 90-110.

Johansen, D. A. (1940). Plant microtechnique, McGraw-Hill Book Company, Inc., New York, London.

Khan, I. A. and Abourashed, E. A. (2009). Leung's Encyclopedia of Common Natural Ingredients: Used in Food, Drugs and Cosmetics, 3rd edition edn, Wiley, Hong Kong.

Pakravan, M., Abedinzadeh, H. and Safaeepur, J. (2007). Comparative Studies of Mucilage Cells in Different Organs in Some Species of Malva, Althaea and Alcea, Pakistan Journal of Biological Sciences 10(15): 2603-2605.

Ph.Eur.8.0. (2013). European Pharmacopoeia 8.0, Council of Europe, Strasbourg.

Rančić, D., Dražić, S., Dajić Stevanović, Z. and Radošević, R. (2009). Anatomical features of the marshmallow (Althaea officinalis L.), J. Sci. Agric. Research 70: 51-60.

Ruzin, S. E. (1999). Plant Microtechnique and Microscopy, Oxford University Press, USA, New York.

Schmidgall, J., Schnetz, E. and Hensel, A. (2000). Evidence for Bioadhesive Effects of Polysaccharides and PolysaccharideContaining Herbs in an ex vivo Bioadhesion Assay on Buccal Membranes, Planta Medica 66(1): 48-53. 